\title{
"I Feel Nervous and Lose My Ideas When Having Presentation": Mapping Senior Students' Challenges in Academic Oral Presentation in English
}

\author{
Marham Jupri Hadi* \\ English Education Department \\ University of Nahdlatul Wathan \\ Mataram, Indonesia \\ marhamhadi@gmail.com
}

\author{
Baiq Henny Rizka \\ English Education Department \\ University of Nahdlatul Wathan \\ Mataram, Indonesia
}

\author{
Tarmizi Tarmizi \\ Beruga' Alam College \\ East Lombok, Indonesia
}

\begin{abstract}
This study explored senior students' challenges when presenting their research proposal and thesis in English. This study was conducted in the English Teacher Education Department of the University of Nahdlatul Wathan Mataram. Five students who did their final project and five lecturers who were involved in reviewing activities were investigated in this study. The results of this study were expected to better understand students' major problems, sources of problems and how these could be tackled. A qualitative case study was employed to conduct this investigation. Observations, focus group discussions, and in-depth interviews were used to collect the data. The data were analyzed by using qualitative content analysis. The findings of this study revealed several students' difficulties in giving oral presentations. They are: a) lack vocabulary, b) anxiety, c) poor understanding of their research proposal, d) not confident to have presentation in English, e) poor display of presentation, f) eye contact, and g) poor speaking skills including pronunciation issues. These difficulties are mostly related to psychological and linguistic aspects. This study also revealed recommendations to tackle these issues, including a) vocabulary enrichment through reading, b) presentation rehearsal, c) observing other students when having presentation, d) learning to make effective and interesting slides, e) learning most commonly used phrases for presentation, $\mathrm{f}$ ) practice in using mind mapping and small cards to organize ideas.
\end{abstract}

Keywords - academic oral presentation, psychological, linguistics, EFL.

\section{INTRODUCTION}

Giving oral presentation is one of the required skills that each student of the English Teacher Education program should master. Students' success is in the university environment and their future jobs require them to be able to express their ideas clearly in spoken English [1]. However, initial observation on how students presented in class revealed that the students encountered several difficulties which affected their overall performance. This study investigated difficulties encountered by senior students' when presenting their research proposal in English. This study was conducted in the English Teacher Education Department, University of Nahdlatul Wathan Mataram.

In the English language education department, each student is required to present their research proposal before getting approval to do data collection. Such a presentation aims at exploring students' understanding of their research project. It further allows supervisors to meet and share their thoughts about their supervised students' research proposals. It is expected that disseminating their proposals and getting feedbacks from supervisors and examiners would improve the quality of students' proposals and enable them to gain more clear viewpoints of how their study will be carried out.

This study was intended to answer the following research questions:

1. What are the students' difficulties and the perceived causes in giving academic oral presentation in English?

2. How can these difficulties be resolved?

\section{A. Oral Presentation Skills}

Oral communication encompasses formal presentations to participate in teams and meetings [2]. For undergraduate students, in particular those studying in their final year, should learn how to effectively present their research projects. It even becomes a more important part of foreign language teaching [3], for instance, to assess students' productive language skills. To succeed in giving an oral presentation, it is worth understanding the key elements of successful oral presentation. As cited from the [4], five aspects should be taken into account namely: preparation, knowing the audience, mastering the content, visual aids, hand-outs, presentation and delivery rehearsal, and acknowledgment.

\section{B. Benefits of Integrating Oral Presentation in ESL Classrooms}

An oral presentation is beneficial in many ways, especially when used in the classroom. Not only does it allow L2 learners to use their language to communicate with others, but it also enhances their language skills and learners' autonomy [1], [5]. In line with this, [6] found the use of oral presentation in the classroom is likely to create greater class interaction and participant as well as, an increased interest in learning, and noticeable signs of progress in their students' communication and presentation skills. Other studies also prove that oral presentation could help bridge the gap between language study and its use in that learners are required to use all four language skills in a naturally integrated way [5]. [1] further proposed five advantages of integrating oral presentation in the ESL classroom. They promote student-centered learning; they require the use of all four language skills; they provide students with realistic language tasks; they have value outside the language classroom, and they improve students' motivation.

\section{Difficulties in Academic Oral Presentation}

A plethora of scholarly studies have discussed this topic. A recent study by [7] revealed that EFL students face time management issues and ineffective presentation. They cannot 
present the most important points while running out of time. [8] further postulates that both native and non-native speakers experience linguistic and psychological difficulties with academic oral presentations. [9] adds that presentation difficulty is mostly related to personal traits (students' fear of evaluation, avoidance of the instructor's eyes, and forgetting what they want to say) and "lack of oral presentation courses, technology-based equipment, a suitable environment, and ample time allowed for the presentation"(p.148).

\section{Perceived Causes}

Brooks identified numerous causes of the occurrence of students' difficulty when asking to present orally in the ESL classroom [1]. First, students might lack presentation skills. They might also have an issue with language skills particularly oral communication. If these skills are not taught in a properly scaffolded way, they might not be able to gain the skills and as a result this causes them to feel less prepared for an effective presentation. Brooks adds that lack of opportunity given to the students to use spoken English appears to another cause of these issues. Furthermore, he pointed out that when students are not less familiar with oral presentation, they would feel uncomfortable and shy particularly when being asked to use English to speak in front of their peers.

Another cause of students' difficulty in having presentation in English is language anxiety. Language anxiety comprises of communication apprehension, test anxiety and fear of negative evaluation [10]. Language anxiety in its simplest sense is a feeling of fear causing students to feel that giving a presentation is a difficult task. Adding to that, [11] identified a list of issues causing students' difficulties in giving oral presentation in English, namely negative perception on oral presentation, Lack of opportunities to speak in English, lack of practice or experiences in giving presentation, lack of preparation, linguistics factors (such lack of English proficiency), psychological issue (lack of self-confidence), and lack of guidance from their teachers.

\section{E. Strategies to Promote Oral Presentation Skills}

Extensive studies have been conducted concerning strategies of how students' oral presentation skills could be enhanced. The use of video presentations is of great help to enhance students' oral skills presentation [12]. In their study, they found that using video presentations provides an opportunity for students to actively engage in their learning and to increase their motivation to do their presentation. Furthermore, the participating students experienced an improvement in their language, facial expressions, and eye contact as a result of being able to watch themselves on the video screen.

Another recommendation of how we could assist students to enhance their oral presentation skills has been discussed. He suggests that setting up an oral presentation class as a strategic step to tackle students' difficulties [1]. In this class, students should be taught the organization or genre of presentation; macro and micro-skills of presentation; and the use of visual aids. Finally, the students should be encouraged to do self-reflection on their presentations. In regards to selfreflection, students and lecturers could use the presentation rubric to help them assess their performance. The rubric focuses on assessing ideas organization, language use, and delivery aspect [13].

\section{METHOD}

This study was qualitative in nature as it was conducted in a natural setting and to gain deep insights from the participants being investigated. This study did not aim to generalize findings; however, the results could be transferred to a similar context. The participants of this study were five students doing their final projects and five lecturers who took part as supervisors and examiners. Data were collected through observations, focused group discussions, questionnaires. In this study, the researchers act as a key instrument. Observations were done three times as the students' presentations were carried out in four sessions. Each student presented on a set schedule. Each student was given 10 minutes at most to present their research proposal and 20 minutes were allocated for discussion. While observing students giving a presentation, the researchers took some notes. After completing the presentation, all students and lecturers were encouraged to ask questions about their proposals. After getting a few questions from students and lecturers, each presenter could return to his or her seat to listen to another presenter.

Another method for collecting data was through focused group discussion with the supervisors and examiners. A focused group discussion was done after the presentation session. The researchers did the FGD only once as it was difficult to get all the lecturers to sit together. Hence, the researchers employed in-depth interviews to gain more data from lecturers. The data provided by the lecturers were mainly based on their observations during the students' presentation. Other sources of data in this study were from interviews with the students, asking reflections about their presentations. In the questionnaires, they were asked to respond to three questions, including their problems in presenting in English, what they did to tackle their problems, possible causes of these problems and how these problems could be better resolved. The collected data were analyzed inductively by employing the interactive approach [14].

\section{RESULTS AND DISCUSSION}

\section{A. Difficulties and perceived causes of oral presentation}

There are four psychological barriers students face when giving an oral presentation, namely: shyness, lack of confidence, lack of motivation, and anxiety [15]. The findings of this study found similar issues where most of the students admitted that they felt such difficulties. The causes of such issues were related to linguistic aspects such as lack of vocabulary. Further, it is found that there are some issues that the students encountered when presenting their proposal in English. First, it appears that lack of vocabulary was the students' main issue before presenting their research proposals. Lack of vocabulary affected their confidence to present in English. Another student said that he was anxious to make mistakes. Such anxiety was caused by feeling fear of making mistakes and being evaluated by examiners. The other student said that he felt nervous during the presentation due to linguistic issues, fluency, and vocabulary.

"I feel nervous when presenting and I don't feel confident with my speaking skills. I am not fluent and I have limited vocabulary" (Excerpt from the interview) 
Based on the interviews with the students, it is found that their anxiety to speak and lack of self-confidence were mainly caused by linguistic aspects such as lack of vocabulary, lack of understanding of grammatical patterns and incorrect pronunciation. One of the lecturers observed a similar issue. He also observed that the students had issues related to vocabulary, grammatical issues, nervous and lack of confidence. It is evidenced that both linguistics and psychological issues are apparent difficulties [16].

Another lecturer observed that the students appeared to be afraid of making mistakes when giving a presentation. This was due to their lack of preparation. He also stated that students did not fully comprehend their research proposals. He suspected that the students did not try to read their proposals in depth. Further, the researchers asked the examiner about the possible causes of these problems. He opined that the causes of these problems were related to the absence of presentation training during the supervision process and student's low motivation for reading their proposals.

The researchers also noticed that students were unconfident to present their proposal in English. Some of them eventually mixed Indonesian and English in their presentation. When asked about the reason, they said that they were lack of vocabulary and encountered problems with their grammar. Such linguistic issues made them feel doubtful to give a presentation in English. To respond to students who could not fully present in English, the examiner eventually encouraged the students to switch or mix their English with Indonesian whenever they found it hard to explain their thoughts in English.

Besides vocabulary and anxiety, the researchers witnessed that some students did not present. Instead, they only read aloud. As a result, they did not maintain eye contact with the audience because they only focused on reading on their laptops and the slides. Possibly, this was caused by not having the confidence to speak in a formal setting before many people. It also observed that most of the students had pronunciation issues. Some words or phrases were mispronounced. Besides, some also misused words and expressions. For instance, a student used "I want to Presentate" which he meant he wanted to present. This is related to the linguistic aspect of the presentation.

Another obvious issue was related to the display. Most of them did not make a professional design. There were too many words on their slides. Some of them even only copied and pasted their proposal onto the slides. This made their slides like a page of a book. Besides too many words, some students also put irrelevant images and animations on their slides. Inappropriate animations misguided the idea presented. For instance, a student put an animation of a drunken man on her slide while the image was not relevant to the concept of bilingual learner she presented.

\section{B. Strategies to tackling students' difficulties}

Having gained insights about students' problems in giving a presentation, the researchers then asked their views about strategies to tackle these issues. One of the students reported that they need to have a lot of practices before having to give oral presentation, their assignments should include oral presentation". A student's response indicates that he was aware of the appropriate strategy to tackle his problems in giving a presentation, by having a lot of practices before proposal presentation. He is also aware that other subjects should include oral presentation as a way their lecturers assess their achievement.

Another student argued that the way to tackle the problem was by mastering the material to be presented and enriching vocabulary related to the presented topic. This student argued that extending speech in English can be achieved if he has sufficient vocabulary related to the topic presented. Such a strategy is related to enhancing the linguistic aspect of oral presentation.

Further, another student believed that the first thing to do is by encouraging himself to speak. He opined that his courage could come from material mastery and vocabulary enrichment, which are associated with both linguistic and psychological aspects of oral presentation. It is necessary to create an opportunity to develop and practice their communication skills [7]. This is in line with the recommendation of the participating lecturer in this study. He suggested that the students should do a lot of rehearsals and if they lack vocabulary and read a lot to gain more new vocabularies.

The lecturer also mentioned the importance of attending pre-presentation sessions in which students could be more prepared to give a presentation; however, there were only a few of them who participated. He also referred to his own experiences when having to give oral presentations in proposal seminar and thesis defense. He said that he had to attend several students' presentations and received feedback from his peers and supervisors. He found such experiences were helpful to prepare him better. Further, he emphasized the importance of including presentation training as part of final project supervision. Even Brooks recommends designing a specific class on oral presentation as a strategy to better prepare students to give an oral presentation in English [1].

The researchers, further, asked if it was necessary to observe how other students presented to improve their presentation skills. Both students and lecturers agreed with such idea as observation allows them to see what a good presentation was and how effective presentation looked like. Observing their peers is also necessary. Many of them opined that their "poor slide" was due to their first time to make a presentation. Concerning inappropriate images, the lecturers provide direct feedback to students. It was likely that the students became aware of what images were needed to make slides meaningful and interesting.

Based on the focus group discussion with the participants (lecturers and examiners), there is plenty of recommendations that are worth taking into account. First, as most of them were not confident with their ability to present in English, hence, they must do a lot of presentation rehearsals before giving an oral presentation. Confidence is related to the psychological aspect of the presentation. The following figure provides suggested steps to go through to better prepare the student for oral presentation.

Sharing ideas with their partners would allow them to learn to communicate their ideas with no psychological barriers. They might feel more relaxed to express their ideas as such can be done in one to one. This further provides them chances to learn to structure their thoughts and pour their ideas. It is expected that their partners would give them feedback afterward. The next step would be encouraging 
them to practice giving a presentation before their peers. This, however, is a bit more formal as they have to provide slides or a summary of their proposals. Of course, there would be mental pressure at this stage, yet it is not much. Their peers would provide feedback to them. Doing this would allow them to gain confidence to communicate their ideas in a formal setting.

$\left[\begin{array}{c}\text { Practice } \\ \text { Sharing } \\ \text { ideas to } \\ \text { Partners } \\ \text { (to learn } \\ \text { communi } \\ \text { cating; no } \\ \text { pressure) }\end{array}\right] \Rightarrow\left(\begin{array}{c}\text { Practice } \\ \text { presenting } \\ \text { before } \\ \text { peers (to } \\ \text { gain } \\ \text { confidence } \\ \text { and } \\ \text { feedback; } \\ \text { less } \\ \text { pressure }\end{array}\right) \Rightarrow\left[\begin{array}{c}\text { Practice } \\ \text { presenting } \\ \text { before } \\ \text { supervisors } \\ \text { (to gain } \\ \text { feedback } \\ \text { and } \\ \text { confidence; } \\ \text { more } \\ \text { pressure) }\end{array}\right) \Rightarrow\left[\begin{array}{c} \\ \text { Real } \\ \text { oral } \\ \text { presentat } \\ \text { ion and } \\ \text { under } \\ \text { bigger } \\ \text { pressure }\end{array}\right.$

Fig. 1. Suggested steps to encourage students for having better presentation

The following rehearsal is to give a presentation before their supervisors, and their peers if possible. More pressure should be expected at this stage as it would be more formal. From their supervisors, students would get a lot of feedback to refine their slides, to organize their presentations, to vary expressions used for presentation, to develop ideas and to end a presentation. More importantly, they could learn what to include or omit in the presentation. They might also get feedback concerning their gestures. The participants of the FGD believed that by having been doing several rehearsals, the students would feel more prepared mentally and technically to give an oral presentation before the board of examiners and audiences.

Besides rehearsals, students are also encouraged to do the following suggestions to improve their performance in giving an oral presentation are as follows. First, they should observe other students having presentations in English. This allows them to learn how the presentation should be done. Second, they should learn the most commonly used phrases or expressions in a presentation. With this, they could structure their presentation better and they could lead the presentation more systematically. Instances of such phrases are expressions used to greet the audience, to change ideas, to move from one slide to another and to sum up ideas. The students also need to practice managing time because each of them is given 10 minutes at most to present all of their points, they should manage their time for presenting each component of their proposals. Further, they should do a lot of practice to communicate their ideas and that doing this like telling a story would be more interesting as this allows the presentation to become more enjoyable and alive.

From the focused discussion with the lecturers and examiners, some other recommendations to enhance their presentation skills and performance were also revealed. First, students could apply mind mapping techniques to organize ideas before presenting. Second, they can use small cards to help them remember the materials being presented. The cards can be used to help them organize their ideas while presenting and to keep them on track. What is more, they need to learn how to make effective and interesting presentation slides.

\section{CONCLUSION}

Based on the results of the research and discussion, it can be concluded that there is no difference in learning outcomes that were taught by using photographic pictures with video as learning media in Biological Science subject on class VIII at junior school 23 Mataram Academic Year 2017/2018.

\section{REFERENCES}

[1] G. Brooks and J. Wilson, "Using oral presentations to improve students' English language skills," Kwansei Gakuin Univ. Humanit. Rev., 2014.

[2] M. Rahman Mojibur, "Teaching Oral Communication Skills: A Taskbased Approach.(research project of assistant professor) Indian School of Mines University.” Dhanbad, 2010.

[3] R. Miles, "Oral presentations for English proficiency purposes," Reflections English Lang. Teach., vol. 8, no. 2, pp. 103-110, 2009

[4] Anonim, "Effective Oral Presentations," Center of Innovation in Research and Teaching, 2018. https://cirt.gcu.edu/research/developmentresources/tutorials/oralpresent (accessed Sep. 26, 2019).

[5] J. King, "Preparing EFL learners for oral presentations," Dong Hwa J. Humanist. Stud., vol. 4, pp. 401-418, 2002.

[6] T. Girard, M. Pinar, and P. Trapp, "An exploratory study of class presentations and peer evaluations: Do students perceive the benefits," Acad. Educ. Leadersh. J., vol. 15, no. 1, pp. 77-93, 2011.

[7] I. Imaniah, "The Studens'difficulties In Presenting The Academic Speaking Presentation," Globish An English-Indonesian J. English, Educ. Cult., vol. 6, no. 1, pp. 44-51, 2018.

[8] N. Morita, "Discourse Socialization through Oral Classroom Activities in a TESL Graduate Program," TESOL Q., 2000, doi: $10.2307 / 3587953$.

[9] N. A. Al-Nouh, M. M. Abdul-Kareem, and H. A. Taqi, "EFL College Students' Perceptions of the Difficulties in Oral Presentation as a Form of Assessment," Int. J. High. Educ., 2015, doi: 10.5430/ijhe.v4n1p136.

[10]E. K. Horwitz, M. B. Horwitz, and J. Cope, "Foreign Language Classroom Anxiety," Mod. Lang. J., 1986, doi: 10.2307/327317.

[11]M. K. G. Whai and L. L. Mei, "Causes of academic oral presentation difficulties faced by students at a polytechnic in Sarawak," English Teach., vol. 44, no. 3, p. 132, 2015.

[12]N. Ag Ahmad and B. Peter Lidadun, "Enhancing Oral Presentation Skills Through Video Presentation,” PEOPLE Int. J. Soc. Sci., 2017, doi: 10.20319/pijss.2017.32.385397.

[13]A. M. Sharif, "English for oral presentation skills for final year undergraduates: An ESP teaching perspective," J. Teach. English Specif. Acad. Purp., vol. 4, no. 2, pp. 381-390, 2016.

[14]A. . Miles, M.B \& Huberman, An expanded sourcebook: Qualitative data analysis (2nd Edition). 1994

[15]M. Jannah and S. W. Fitriati, "Psychological problems faced by the year-eleven students of MA Nuhad Demak in speaking English," English Educ. J., vol. 6, no. 1, 2016.

[16]J. Juhana, "Psychological factors that hinder students from speaking in English class (A case study in a senior high school in South Tangerang, Banten, Indonesia)," J. Educ. Pract., vol. 3, no. 12, pp. 100-110, 2012. 